\begin{tabular}{c|c|c}
\hline Jurnal Penelitian Farmasi \& Herbal & Vol. 3 No. 1 & Edition: November 2020 - April 2021 \\
\hline \multirow{2yn}{*}{ Received: 21 September 2020 } & http://ejournal.delihusada.ac.id/index.php/JPFH & Accepted: 27 Oktober 2020 \\
\cline { 2 - 3 } & Revised: 08 Oktober 2020 &
\end{tabular}

\title{
UJI EFEKTIVITAS EKSTRAK ETANOL DARI KULIT PISANG KEPOK (Musa Paradisiaca) UNTUK PENYEMBUHAN LUKA SAYAT PADA TIKUS
}

\author{
Bunga Mari Sembiring, Sufriyadi Nasution \\ Fakultas Farmasi, Institut Kesehatan Deli Husada Deli Tua \\ e-mail: bungamerisembiring@gmail.com
}

\begin{abstract}
Banana peel turns out to have many benefits, one of which is that it can be used to accelerate the wound healing process. Banana peel (Musa Paradisiaca L.) ripe yellow skin is rich in flavonoid compounds, as well as other phenolic compounds, besides containing a lot of carbohydrates, minerals such as potassium and sodium and cellulose. This study aims to determine the wound healing effect of cuts using the Ethanol Extract of Kepok Banana Skins in Rats. Determine the concentration of ethanol extract of Kepok banana peel which is the most effective in healing wound cuts in mice. Knowing a significant difference to the acceleration of wound healing between ethanol extracts of Kepok banana peel and betadin. Research methods conducted included characterization, effectiveness test of ethanol extract of Kepok banana peel, manufacture of extract by maceration using ethanol $96 \%$ solvent, test of effectiveness of ethanol extract of kepok banana peel on cut wounds in mice. Data analysis using SPSS is Anova One Way Test. From the results of this study the ethanol extract of Kepok banana peel can have an effect on wound healing in mice. Ethanol extract of Kepok banana peel is faster than betadin in healing wound cuts in mice. Ethanol extract of Kepok banana peel with a dose of $750 \mathrm{Mg} / \mathrm{kg} \mathrm{BW}$ is the most effective in healing wound cuts in rats.
\end{abstract}

Keyword : Kepok Banan Skin, betatins, mice

\section{Pendahuluan}

Kulit adalah organ terluar tubuh manusia. Luas kulit orang dewasa adalah 1,5 meter persegi dan beratnya sekitar $15 \%$ dari berat badan. Kulit memiliki peran yang sangat penting bagi manusia. Salah satu fungsi utama kulit adalah melindungi dari gangguan dari luar tubuh, baik itu gangguan fisik maupun mekanis (Wasitaamdja, 2007). Luka mengacu pada hilangnya atau rusaknya bagian jaringan tubuh, atau rusaknya unit / komponen jaringan, terutama adanya bahan jaringan yang rusak atau hilang. Ketika cedera terjadi, berbagai efek dapat terjadi, termasuk hilangnya fungsi organ secara total atau sebagian, stres saraf simpatis, perdarahan dan pembekuan darah, kontaminasi bakteri dan kematian sel (Kaplan, 1992). Luka mungkin 
hanya berupa kerusakan epidermis, mengenai sebagian epidermis dan dermis, bahkan menembus kulit luar dermis hingga mencapai jaringan subkutan, otot bahkan tulang, tergantung dari faktor penyebab cedera tersebut (Judd, 2007).

Menurut berbagai sebab, terdapat berbagai jenis luka, antara lain luka terbuka dan luka tertutup. Contoh luka terbuka adalah sayatan. Sayatan adalah luka yang terjadi akibat sayatan alat tajam, seperti sayatan akibat operasi. Sayatan ditandai dengan luka terbuka, nyeri, dan panjang luka lebih besar dari kedalaman luka (Berman, 2009). Dalam hal mengobati luka dibandingkan dengan pengobatan modern, tumbuhan tradisional memiliki daya tarik yang langgeng, karena tumbuhan tradisional mempunyai ciri-ciri alam yang dianggap lebih aman dan lebih baik oleh masyarakat. Pengobatan tradisional mudah didapat karena masyarakat dapat memperoleh pengobatan tradisional tanpa resep dokter. Selain itu harganya relatif murah dan efek sampingnya minimal (Juckett, 2004). Keunggulan lain dari tumbuhan obat adalah tumbuhan obat dapat ditemukan secara luas (Agarwal, 2008). Beberapa tumbuhan obat yang digunakan sebagai bahan untuk mempercepat proses penyembuhan luka antara lain kulit pisang (Musa Paradisiaca L), lidah buaya (Aloe Vera), kunyit (Curcuma Longa Linn) dan kacang polong merpati (Centella Asiatica) (Agarwal, 2008). Sebagai manusia yang rasional dan pencari ilmu, hendaknya kita melakukan penelitian ilmiah, seperti penelitian berbagai tumbuhan, untuk mengetahui manfaat dan potensi satu atau lebih tumbuhan (salah satunya pisang). Pisang merupakan salah satu tanaman buah yang berasal dari Asia Tenggara berupa tumbuhan obat, termasuk Indonesia (Warintek, 2011). Di Indonesia sendiri terdapat lebih dari 230 jenis pisang, namun pisang yang biasa dijual dan dikonsumsi di pasaran adalah Pisang Lumut Ampang, Pisang Huang Ampang, Pisang Barangan, Pisang Tumbuhan, Pisang Kipke, Pisang Tanduk dan Pisang Mas (Made Astawan, 2009 ).

Kulit pisang memiliki banyak manfaat, salah satunya dapat digunakan untuk mempercepat proses penyembuhan luka. Kulit kuning buah pisang yang matang (Musa Paradisiaca L.) kaya akan flavonoid dan senyawa fenolik lainnya, serta juga banyak mengandung karbohidrat dan mineral (seperti kalium, natrium dan selulosa). Kulit pisang juga mengandung tanin, steroid dan saponin (Akpuaka, 2011) karena kandungan airnya yang tinggi dapat menurunkan inflasi dan kalori. Sesuai dengan sifat formulanya, untuk mendapatkan ekstrak kulit pisang Kepok (Musa Paradisiaca L.) yang baik dan efektif harus ditentukan konsentrasi ekstrak yang tepat.

Berdasarkan uraian di atas maka peneliti tertarik untuk menguji khasiat ekstrak etanol dari kulit kulit pisang kepok (Musa Paradisiaca L.) untuk menyembuhkan luka pada mencit untuk pengobatan luka sayatan 
secara tradisional.Peneliti berharap penelitian sebelumnya dapat mendukung yang lain. Data Ilmiah. Dalam pemanfaatan kulit pisang kepok.

\section{METODE PENELITIAN}

Penelitian ini merupakan penelitian eksperimental. Eksperimen merupakan kegiatan eksperimental yang dirancang untuk mengetahui semua gejala atau efek setelah perawatan, meliputi beberapa tahapan, meliputi pengumpulan, kesederhanaan pembuatan, identifikasi metabolit sekunder, skrining fitokimia, dan pengujian penyembuhan luka ekstrak etanol kulit pisang kapuk. Efektivitas (menggunakan metode maserasi (Mus paradisiacal L.)

\section{Metode Pengambilan Sampel}

1. Identifikasi Sampel

Untuk mendapatkan klasifikasi sistem atau klasifikasi tanaman yang akurat, sampel kulit pisang kepok diobservasi di herbarium hayati.

\section{Pengambilan Sampel}

Sampel yang digunakan dalam penelitian ini adalah kulit pisang kepok (Musa paradisiaca L.) yang diambil dari Kecamatan Deli Tua Kabupaten Deli Serdang. Pengambilan sampel bertujuan, dan tidak ada perbandingan dengan sampel yang sama di tempat lain.

\section{Pembuatan Simplisia}

Sampel yang digunakan dalam penelitian ini adalah kulit pisang kepok. Langkah sederhana membuat dari kulit pisang kepok adalah penyortiran basah, lalu dicuci dengan air mengalir, kemudian dijemur di lemari pengering, lalu dilakukan penyortiran kering. Setelah itu contoh tanaman dibuat menjadi bubuk (sederhana).

\section{Pembuatan Ekstrak}

Timbang 500 gram sampel sederhana kering ke dalam wadah kaca gelap, rendam dengan ethanol $96 \%$, tutup 75 bagian, dan tempatkan di tempat gelap selama 5 hari sambil diaduk sesekali, kemudian saring, lalu Ampas dipindahkan ke wadah kemudian diperas dan dicuci dengan 25 bagian etanol dari $96 \%$ menjadi 100 bagian ekstrak. Selain itu, filtrat yang diperoleh dipindahkan ke wadah tertutup, kemudian dikumpulkan Maserat, kemudian pelarut diuapkan menggunakan rotary evaporator pada suhu $\pm 40^{\circ}$ $C$ untuk mendapatkan ekstrak yang kental.

\section{Alat Dan Bahan}

1. Alat

Alat yang digunakan pada penelitian ini yaitu alat alat gelas, Bunsen, cawan porselin, jangka sorong, penangas air, pisau bedah steril, thermometer, timbangan analitik, tabung reaksi, Erlenmeyer $100 \mathrm{ml}$, Erlenmeyer $250 \mathrm{ml}$ (pyrex),rotary evaporator, batang pengaduk, beaker glass $250 \mathrm{ml}$ (pyrex), cawan porselin), gelas ukur $500 \mathrm{mg}$ (pyrex), gelas ukur $250 \mathrm{ml}$ (pyrex), gelas ukur $100 \mathrm{ml}$ (pyrex), pipet tetes, tabung reaksi (pyrex), hot plate, telenan 
2. Bahan

Bahan yang digunakan adalah ekstrak kulit pisang paling pekat (Heaven Rat), asam klorida $2 \mathrm{~N}$ (HCL), sulfat pekat (H2SO4), besi (III) klorida (FeCl3). Etanol 96\%, salep betain, lidokain, N-heksana, asam asetat anhidrat, pentanol, $\mathrm{HCl} 2 \mathrm{~N}$, $\mathrm{HCl}(p), \mathrm{HCl}(e)$, Aqua, reagen Meyer, reagen Bouchart, reagen Dragendrof dan Reagen berminyak.

\section{Prosedur Penelitian}

1. Pemeriksaan

Simplisia

Menurut

pemeriksaan

kesederhanaan yang dilakukan oleh

Organisasi Kesehatan Dunia (1992), seperti penentuan kadar air. Penentuan kadar ekstrak larut air, penentuan kadar ekstrak larut etanol, penentuan kadar abu tidak larut asam. POM (2000).

\section{Pemeriksaan Makrokospik}

Pemeriksaan makroskopis dilakukan dengan mengamati bentuk luar yaitu ukuran, bentuk, warna, bau, dan rasa bentuk sederhana dari kulit pisang kepok (Musa paradisiacal L.).

\section{Pemeriksaan Mikroskopik}

Uji mikroskopis meliputi pengamatan sel serbuk sederhana kulit pisang kepok (Musa paradisiacal L.) sederhana, isi sel atau fragmen kontak berupa jaringan tanaman, dan pengamatan di bawah mikroskop.

4. Penetapan Kadar Sari Larut dalam Air

Dalam labu tersumbat, berat total $5 \mathrm{~g}$ ekstrak etanol dalam $100 \mathrm{ml}$ kloroform air (diencerkan dengan 2,5 $\mathrm{ml}$ kloroform menjadi 1 liter) direndam selama 24 jam, sambil sesekali dikocok selama 6 jam pertama, kemudian didiamkan selama 18 jam. , Lalu filter. Menguapkan $20 \mathrm{ml}$ filtrat pertama sampai kering dalam evaporator dasar datar berbentuk kerucut, dan panaskan sisanya hingga berat tetap pada suhu $1050 C$. Hitung persentase konsentrasi ekstrak larut air pada bahan kering (Depkes, RI, 1995).

\section{Penetapan Kadar Abu Total}

Sebanyak 2 gram ekstrak etanol yang ditumbuk dan ditimbang dengan hati-hati ditempatkan dalam wadah porselen berpijar dan dikupas, lalu dihaluskan. Pelayaran anil perlahan sampai arang habis, berpijar selama 3 jam pada suhu $600^{\circ} \mathrm{C}$, kemudian pendinginan dan penimbangan sampai diperoleh berat tetap. Kadar abu dihitung berdasarkan bahan kering (Depkes, RI, 1995).

6. Penetapan Kadar Abu Tidak larut dalam asam

Abu yang diperoleh pada penentuan abu direbus dalam 25 $\mathrm{mL}$ asam klorida encer selama 5 menit, bagian asam yang tidak larut dikumpulkan, disaring dengan kertas saring bebas abu, dicuci dengan air panas, dianil, kemudian didinginkan dan ditimbang hingga berat tetap. Kadar abu tidak larut asam dihitung berdasarkan bahan yang telah dikeringkan di udara (Depkes, RI., 1995). 


\section{Pembuatan Pereaksi}

1. Larutan Pereaksi Meyer

Reagen Meyer dibuat dengan menambahkan $5 \mathrm{~g}$ kalium iodida ke dalam $10 \mathrm{ml}$ air baku, kemudian menambahkan larutan $1,36 \mathrm{~g}$ merkuri (II) klorida ke dalam $60 \mathrm{ml}$ air suling. Kemudian kocok larutan tersebut dan tambahkan air hingga $100 \mathrm{ml}$ (Marjoni, 2016).

\section{Larutan Pereaksi Dragendrof}

Sebanyak $8 \mathrm{~g}$ bismut nitrat dilarutkan dalam $20 \mathrm{ml} \mathrm{HNO}_{\text {, }}$ kemudian dicampur dengan $27,2 \mathrm{~g}$ kalium iodida dalam $50 \mathrm{ml}$ akuades. Campuran benar-benar terpisah. Ambil larutan bening dan encerkan hingga $100 \mathrm{ml}$ dengan air secukupnya (Marjoni, 2016).

\section{LarutanPereaksiBouchard}

Sebanyak 4g KI dilarutkan dalam $20 \mathrm{~mL}$ air, kemudian ditambahkan $2 \mathrm{~g}$ iodium sambil diaduk sampai larut. Hingga $100 \mathrm{ml}$ pewarna air (Marjoni, 2016).

4. LarutanPereaksiBesi(III)Klorida $1 \%$

Larutkan maksimal $1 \mathrm{~g}$ besi (III) klorida dalam akuades hingga $100 \mathrm{ml}$, lalu saring (Marjoni, 2016).

\section{Larutan pereaksi $\mathrm{HCl} 2 \mathrm{~N}$}

Sebanyak $17 \mathrm{ml}$ asam klorida pekat diencerkan menjadi $100 \mathrm{ml}$ (Marjoni, 2016).

\section{Uji Skrining Fitokimia}

a. Alkaloid

Timbang 0,5 g bubuk simplisia, lalu tambahkan $1 \mathrm{ml}$ asam klorida $2 \mathrm{~N}$ dan $9 \mathrm{ml}$ air suling, panaskan pada penangas air selama 2 menit, dinginkan, lalu saring. Filtrat digunakan dalam percobaan berikut:
1. Ambil 3 tetes filtrat, lalu tambahkan 2 tetes reagen untuk menghasilkan endapan berwarna putih / kuning.

2. Ambil 3 tetes filtrat, kemudian tambahkan 2 tetes pereaksi bouchart hingga terbentuk endapan berwarna coklat kehitaman

3. Ambil 3 tetes filtrat, kemudian tambahkan 2 tetes reagen Dragendoft untuk menghasilkan endapan berwarna merah bata (Marjoni, 2016)

b. Flavonoid

Tambahkan total $0,5 \mathrm{~g}$ bubuk sederhana ke $100 \mathrm{ml}$ air panas. Kemudian rebus campuran tersebut selama kurang lebih 5 menit. Lalu saring selagi panas. Sebanyak $5 \mathrm{ml}$ filtrat diperoleh, 0,1 g bubuk $\mathrm{Mg}$, $1 \mathrm{ml} \mathrm{HCl}$ pekat dan $2 \mathrm{ml}$ pentanol ditambahkan, dikocok, dan dipisahkan. Jika pada lapisan pentanol terdapat warna merah, kuning, atau jingga, maka flavonoidnya bertanda positif (Marjoni, 2016).

\section{Tanin}

Gunakan $10 \mathrm{ml}$ air untuk mengekstrak total $0,5 \mathrm{~g}$ sampel. Ekstrak disaring, kemudian filtrat yang dihasilkan diencerkan dengan akuades hingga tidak berwarna. Encerkan hasilnya menjadi $2 \mathrm{ml}$, lalu tambahkan 1-2 tetes besi (III) klorida. Munculnya warna biru atau kehitaman hijau menandakan adanya tanin (Marjoni, 2016).

\section{Saponin}

Masukkan total $0,5 \mathrm{~g}$ sampel ke dalam tabung reaksi, tambahkan $10 \mathrm{ml}$ air suling panas, dinginkan, lalu kocok kuat-kuat selama 10 detik hingga membentuk busa atau 
buih dengan ketinggian 1-10 cm selama tidak kurang dari 10 menit. Jika ditambahkan 1 tetes larutan $\mathrm{HCl}$ $2 \mathrm{~N}$ maka buih tidak akan hilang yang menandakan adanya saponin (Marjoni, 2016).

Pengujian hewan laboratorium 1. Persiapan hewan percobaan 25 ekor tikus yang digunakan dalam penelitian ini pertama kali diaklimatisasi di dalam kandang selama 2 minggu sambil tetap diberi makan dan minum.

2. Pengujian pada hewan laboratorium Efek penyembuhan luka dilakukan pada hewan coba tikus putih yang sehat, pertama mencukur area yang akan terluka (punggung), kemudian menggunakan pisau bedah (bisturi) steril sepanjang $2 \mathrm{~cm}$ dan dalam $2 \mathrm{~mm}$ untuk mencukur rambutnya. penyembuhan luka. 25 tikus putih digunakan.

a) Kelompok 1: Oleskan ekstrak etanol kulit pisang pepaya $250 \mathrm{~g} / \mathrm{kg}$ berat badan pada luka

b) Kelompok 2: Oleskan ekstrak etanol kulit pisang kepok 500 mg / kg berat badan pada luka

c) Kelompok 3: Oleskan ekstrak etanol kulit pisang kepok 750 Mg / Kg BB pada luka

d) Kelompok 4: Luka dilapisi dengan cairan betaine

e) Kelompok 5: Cat luka dengan bersih

\section{Pengamatan pada Luka}

Dengan mengukur panjang luka menggunakan caliper, mengamati tanda-tanda penyembuhan luka, dan mengamati tahap penyembuhan luka yaitu tahap inflamasi, tahap proliferasi, dan tahap matur, luka diamati setiap hari selama 14 hari.

\section{Metode Analisis Data}

Dalam penelitian ini, data yang diperoleh dari pengukuran panjang sayatan ditabulasi, kemudian dilakukan analisis statistik menggunakan analisis varian satu arah, dan dilampirkan dalam bentuk tabel observasi.

\section{HASIL DAN PEMBAHASAN}

Tabel 1 Hasil pemeriksaan karakteristik simplisia

\begin{tabular}{|c|c|c|c|}
\hline $\mathrm{N}$ & Penetapan/ & & plisia \\
\hline 0 & $\begin{array}{c}\text { karakteristik } \\
\text { Simplisia }\end{array}$ & $\begin{array}{l}\text { Kada } \\
\text { r \% }\end{array}$ & $\begin{array}{c}\text { Persyar } \\
\text { atan } \\
\text { Farmak } \\
\text { ope } \\
\text { Herbal } \\
(\%)\end{array}$ \\
\hline 1 & $\begin{array}{l}\text { Kadar sari } \\
\text { larut dalam } \\
\text { air }\end{array}$ & $\begin{array}{c}16,6 \\
72\end{array}$ & $>7,9$ \\
\hline 2 & $\begin{array}{l}\text { Kadar sari } \\
\text { larut dalam } \\
\text { etanol }\end{array}$ & $\begin{array}{c}9,29 \\
9\end{array}$ & $>3,9$ \\
\hline 3 & $\begin{array}{l}\text { Kadar abu } \\
\text { total }\end{array}$ & $\begin{array}{c}2,83 \\
1\end{array}$ & $<7,2$ \\
\hline 4 & $\begin{array}{l}\text { Kadar abu } \\
\text { tidak larut } \\
\text { dalam asam }\end{array}$ & 0,20 & $<1,2$ \\
\hline
\end{tabular}

Tabel 2 Hasil skrining fitokimia serbuk simplisia kulit buah pisang kepok(Musa paradisiacal L.)

\begin{tabular}{ccc}
\hline No & Pemeriksaan & Hasil \\
\hline 1 & Flavonoid & + \\
2 & Tanin & + \\
3 & Steroida & + \\
4 & Alkaloid & + \\
5 & Saponin & + \\
\hline
\end{tabular}


Keterangan :

$+=$ Mengandung golongan senyawa

- = Tidak mengandung golongan senyawa

\section{Hasil Ekstraksi Serbuk Simplisia}

Dengan menggunakan 5 liter etanol 96\% untuk mengekstrak $500 \mathrm{~g}$ bubuk sederhana, diperoleh $15 \mathrm{~g}$ ekstrak kental.

Tabel 3 Data kelompok pertama memiliki hasil pengukuran panjang luka sayat pada tikus mulai dari hari ke 1 sampai ke 14, sebagai berikut :

\begin{tabular}{|c|c|c|c|c|c|}
\hline \multirow[b]{2}{*}{$\begin{array}{c}\mathrm{Ha} \\
\text { ri } \\
\text { ke }\end{array}$} & \multicolumn{5}{|c|}{ Panjang luka (cm) } \\
\hline & $\begin{array}{c}\text { EEP } \\
\text { K25 } \\
0 \\
\text { Mg } \\
/ \mathbf{K g} \\
\text { BB }\end{array}$ & $\begin{array}{c}\text { EEP } \\
\mathrm{K} \\
500 \\
\mathrm{Mg} \\
/ \mathrm{Kg} \\
\mathrm{BB}\end{array}$ & $\begin{array}{c}\text { EEP } \\
\mathrm{K} \\
750 \\
\mathrm{Mg} \\
/ \mathrm{Kg} \\
\mathrm{BB}\end{array}$ & $\begin{array}{c}\text { Bet } \\
\text { adi } \\
\text { ne } \\
\text { Cair }\end{array}$ & $\begin{array}{c}\text { aqu } \\
\text { ade } \\
\text { st }\end{array}$ \\
\hline $\mathbf{1}$ & 2,0 & 2,0 & 2,0 & 2,0 & 2,0 \\
\hline 2 & 1,8 & 1,3 & 1,1 & 1.6 & 2,0 \\
\hline 3 & 1,7 & 1,3 & 1,0 & 1,5 & 1,9 \\
\hline 4 & 1,6 & 1,2 & 1,0 & 1,5 & 1,8 \\
\hline 5 & 1,5 & 1,1 & 0,9 & 1,4 & 1,7 \\
\hline 6 & 1,3 & 1,0 & 0,8 & 1,3 & 1,6 \\
\hline 7 & 1,1 & 1,0 & 0,7 & 1,2 & 1,5 \\
\hline 8 & 1,0 & 0,9 & 0,6 & 1,2 & 1,4 \\
\hline 9 & 1,0 & 0,7 & 0,4 & 1,2 & 1,3 \\
\hline 10 & 0,9 & 0,7 & 0,2 & 1,1 & 1,2 \\
\hline 11 & 0,8 & 0,6 & 0,2 & 0,9 & 1,0 \\
\hline 12 & 0,4 & 0,2 & 0,1 & 0,7 & 0,8 \\
\hline 13 & 04 & 0,2 & 0,1 & 0,5 & 0,7 \\
\hline 14 & 0,2 & 0,1 & 0 & 0,4 & 0,5 \\
\hline
\end{tabular}

Tabel 4 Data kelompok kedua memiliki hasil pengukuran panjang luka sayat pada tikus mulai dari hari ke 1 sampai ke 14 , sebagai berikut :

\begin{tabular}{|c|c|c|c|c|c|}
\hline \multirow[b]{2}{*}{$\begin{array}{c}\text { Ha } \\
\text { ri } \\
\text { ke }\end{array}$} & \multicolumn{5}{|c|}{ Panjang Luka (cm) } \\
\hline & $\begin{array}{c}\text { EE } \\
\text { PK } \\
25 \\
0 \\
\text { Mg } \\
/ \mathrm{K} \\
\text { g } \\
\text { BB }\end{array}$ & $\begin{array}{c}\text { EE } \\
\text { PK } \\
50 \\
0 \\
\mathrm{Mg} \\
/ \mathrm{K} \\
\mathrm{g} \\
\mathrm{BB}\end{array}$ & $\begin{array}{c}\text { EE } \\
\text { PK } \\
75 \\
0 \\
\mathrm{Mg} \\
/ \mathbf{K} \\
\mathbf{g} \\
\mathbf{B B}\end{array}$ & $\begin{array}{c}\text { Bet } \\
\text { adi } \\
\text { ne } \\
\text { Cai } \\
\text { r }\end{array}$ & $\begin{array}{c}\text { Aqu } \\
\text { ade } \\
\text { st }\end{array}$ \\
\hline 1 & 2,0 & 2,0 & 2,0 & 2,0 & 2,0 \\
\hline 2 & 1,8 & 1,2 & 1,1 & 1,6 & 1,9 \\
\hline 3 & 1,7 & 1,2 & 0,9 & 1,5 & 1,9 \\
\hline 4 & 1,5 & 1,1 & 0,8 & 1,5 & 1,9 \\
\hline 5 & 1,4 & 1,0 & 0,7 & 1,3 & 1,6 \\
\hline 6 & 1,4 & 1,0 & 0,6 & 1, & 1,6 \\
\hline 7 & 1,4 & 1,0 & 0,5 & 1,0 & 1,6 \\
\hline 8 & 1,3 & 0,9 & 0,4 & 1,0 & 1,6 \\
\hline 9 & 1,1 & 0,7 & 0,3 & 1,0 & 1,5 \\
\hline 10 & 1,0 & 0,6 & 0,2 & 0,9 & 1,4 \\
\hline 11 & 0,9 & 0,5 & 0,2 & 0,9 & 1,3 \\
\hline 12 & 0,3 & 0,2 & 0,2 & 0,6 & 0,7 \\
\hline 13 & 0,3 & 0,2 & 0,2 & 0,4 & 0,6 \\
\hline 14 & 0,2 & 0,1 & 0 & 0,3 & 0,4 \\
\hline
\end{tabular}

Tabel 5 Data kelompok ketiga memiliki hasil pengukuran panjang luka sayat pada tikus mulai dari hari ke 1 sampai ke 14, sebagai berikut :

\begin{tabular}{|c|c|c|c|c|c|}
\hline \multirow[b]{2}{*}{$\begin{array}{c}\mathrm{Ha} \\
\mathbf{r i} \\
\mathbf{K e}\end{array}$} & \multicolumn{5}{|c|}{ Panjang Luka (cm) } \\
\hline & $\begin{array}{c}\text { EEP } \\
\text { K25 } \\
0 \\
\mathrm{Mg} \\
/ \mathrm{Kg} \\
\mathrm{BB}\end{array}$ & $\begin{array}{c}\text { EEP } \\
\text { K } \\
500 \\
\mathrm{Mg} \\
/ \mathrm{Kg} \\
\mathrm{BB}\end{array}$ & $\begin{array}{c}\text { EEP } \\
\text { K } \\
750 \\
\mathrm{Mg} \\
/ \mathrm{Kg} \\
\mathrm{BB}\end{array}$ & $\begin{array}{l}\text { Bet } \\
\text { adi } \\
\text { ne } \\
\text { Cair }\end{array}$ & $\begin{array}{c}\text { Aqu } \\
\text { ade } \\
\text { st }\end{array}$ \\
\hline 1 & 2,0 & 2,0 & 2,0 & 2,0 & 2,0 \\
\hline 2 & 1,9 & 1,4 & 1,2 & 1,7 & 1,8 \\
\hline 3 & 1,7 & 1,4 & 1,0 & 1,6 & 1,8 \\
\hline 4 & 1,7 & 1,4 & 0,9 & 1,5 & 1,8 \\
\hline 5 & 1,6 & 1,3 & 0,8 & 1,3 & 1,7 \\
\hline 6 & 1,5 & 1,1 & 0,7 & 1,2 & 1,5 \\
\hline 7 & 1,3 & 1,0 & 0,6 & 1,2 & 1,5 \\
\hline 8 & 1,2 & 1,0 & 0,5 & 1,2 & 1,4 \\
\hline 9 & 1,0 & 0,9 & 0,4 & 1,1 & 1,2 \\
\hline 10 & 0,8 & $\begin{array}{c}0,6 \\
7\end{array}$ & 0,3 & 0,8 & 1,0 \\
\hline 11 & 0,6 & 0,6 & 0,2 & 0,7 & 0,8 \\
\hline 12 & 0,4 & 0,3 & 0,1 & 0,7 & 0,6 \\
\hline
\end{tabular}


$13 \quad 0,3 \quad 0,3 \quad 0 \quad 0,6 \quad 0,5$

\begin{tabular}{llllll}
14 & 0,2 & 0,2 & 0 & 0,5 & 0,3 \\
\hline
\end{tabular}

Tabel 6 Data kelompok keempat memiliki hasil pengukuran panjang luka sayat pada tikus mulai dari hari ke 1 sampai ke 14, sebagai berikut :

\begin{tabular}{|c|c|c|c|c|c|}
\hline \multirow[b]{2}{*}{$\begin{array}{c}\mathrm{Ha} \\
\text { ri } \\
\mathrm{Ke}\end{array}$} & \multicolumn{5}{|c|}{ Panjang Luka (cm) } \\
\hline & $\begin{array}{c}\text { EEP } \\
\text { K2 } \\
50 \\
\text { Mg } \\
/ \mathbf{K g} \\
\text { BB }\end{array}$ & $\begin{array}{c}\text { EE } \\
\text { PK } \\
50 \\
0 \\
\mathrm{Mg} \\
/ \mathrm{K} \\
\mathrm{g} \\
\mathrm{BB}\end{array}$ & $\begin{array}{c}\text { EEP } \\
\text { K } \\
750 \\
\text { Mg/ } \\
\text { Kg } \\
\text { BB }\end{array}$ & $\begin{array}{l}\text { Bet } \\
\text { adi } \\
\text { ne } \\
\text { Cair }\end{array}$ & $\begin{array}{c}\text { aqu } \\
\text { ade } \\
\text { st }\end{array}$ \\
\hline 1 & 2,0 & 2,0 & 2,0 & 2,0 & 2,0 \\
\hline 2 & 1,6 & 1,6 & 0,9 & 1,6 & 1,8 \\
\hline 3 & 1,4 & 1,5 & 0,8 & 1,5 & 1,8 \\
\hline 4 & 1,4 & 1,5 & 0,8 & 1,5 & 1,7 \\
\hline 5 & 1,3 & 1,2 & 0,7 & 1,4 & 1,4 \\
\hline 6 & 1,2 & 1,2 & 0,6 & 1,4 & 1,4 \\
\hline 7 & 1,1 & 1,1 & 0,5 & 1,3 & 1,4 \\
\hline 8 & 1,0 & 1,0 & 0,4 & 1,2 & 1,3 \\
\hline 9 & 0,9 & 1,0 & 0,3 & 1,2 & 1,2 \\
\hline 10 & 0,8 & 0,8 & 0,2 & 1.0 & 1,0 \\
\hline 11 & 0,7 & 0,6 & 0,2 & 0,9 & 0,9 \\
\hline 12 & 0,6 & 0,4 & 0,1 & 0,6 & 0,9 \\
\hline 13 & 0,5 & 0,3 & 0 & 0,5 & 0,8 \\
\hline 14 & 03 & 0,1 & 0 & 0,4 & 0,5 \\
\hline
\end{tabular}

Tabel 7 Data kelompok kelima memiliki hasil pengukuran panjang luka sayat pada tikus mulai dari hari ke 1 sampai ke 14, sebagai berikut:

\begin{tabular}{cccccc}
\hline & \multicolumn{5}{c}{ Panjang Luka (cm) } \\
\cline { 2 - 6 } Ha & EEP & EEP & EEP & Bet & Aqu \\
ri & K2 & K & K & adi & ade \\
Ke & $\mathbf{5 0}$ & $\mathbf{5 0 0}$ & $\mathbf{7 5 0}$ & ne & st \\
& $\mathbf{M g}$ & $\mathbf{M g /}$ & $\mathbf{M g}$ & Cair & \\
& $\mathbf{~ K}$ & $\mathbf{K g}$ & $\mathbf{~} \mathbf{K g}$ & & \\
& $\mathbf{g}$ & $\mathbf{B B}$ & $\mathbf{B B}$ & & \\
& $\mathbf{B B}$ & & & & \\
\hline $\mathbf{1}$ & 2,0 & 2,0 & 2,0 & 2,0 & 2,0 \\
$\mathbf{2}$ & 1,6 & 5 & 1,3 & 1,5 & 1,9 \\
$\mathbf{3}$ & 1,5 & 1,4 & 12 & 1,4 & 1,6 \\
$\mathbf{4}$ & 1,5 & 1,4 & 1,0 & 1,4 & 1,6 \\
$\mathbf{5}$ & 1,4 & 1,3 & 0,9 & 1,3 & 1,5
\end{tabular}

\begin{tabular}{cccccc}
$\mathbf{6}$ & 1,2 & 1,2 & 0,8 & 1,3 & 1,5 \\
$\mathbf{7}$ & 1,0 & 1,0 & 0,7 & 1,2 & 1,4 \\
$\mathbf{8}$ & 1,0 & 1,0 & 0,6 & 1,1 & 1,4 \\
$\mathbf{9}$ & 1,0 & 0,9 & 0,5 & 1,0 & 1,3 \\
$\mathbf{1 0}$ & 0,8 & 0,7 & 0,3 & 0,9 & 1,2 \\
$\mathbf{1 1}$ & 0,7 & 0,6 & 0,2 & 0,7 & 1,0 \\
$\mathbf{1 2}$ & 0,3 & 0,6 & 0,2 & 0,4 & 0,8 \\
$\mathbf{1 3}$ & 0,2 & 0,4 & 0,1 & 0,3 & 0,7 \\
$\mathbf{1 4}$ & 0,2 & 0,2 & 0 & 0,2 & 0,6 \\
\hline
\end{tabular}

\section{SIMPULAN DAN SARAN}

\section{Kesimpulan}

Dari hasil penelitian yang telah dilakukan dapat diambil kesimpulan sebagai berikut:

1. Ekstrak etanol kulit pisang kepok dapat meningkatkan penyembuhan luka pada tikus putih.

2. Dalam penyembuhan luka tikus putih, ekstrak etanol kulit pisang kepok lebih cepat dibandingkan betain.

3. Ekstrak etanol kulit pisang kepok dengan dosis $750 \mathrm{Mg} /$ $\mathrm{kg}$ berat badan paling efektif untuk penyembuhan luka pada tikus putih.

\section{Saran}

Direkomendasikan

agar

peneliti selanjutnya:

1. Gunakan kulit pisang kepok untuk membuat sediaan lain untuk penelitian penyembuhan luka.

2. Melakukan penelitian lain tentang efek kulit pisang kapuk, seperti uji antibakteri.

3. Gunakan ekstrak etanol untuk mempelajari efek penyembuhan luka dari kulit pisang kepok korea.

4. Mengajak masyarakat untuk menggunakan ekstrak etanol kulit pisang kapuk dalam kehidupan sehari-hari. 


\section{DAFTAR PUSTAKA}

Agoes G.2006. Pengebangan Sediaan Farmasi. Edisi Revisi dan Peruasan. Penerbit ITB. Bandung. Akarkhi,A.F.M.,Saifullah,R.Yeoh,S and Azhar,M.E. 2010. Physicochemica Properties of banana Pee Flour as influenced by Variety and Stage of Ripeness. Asian Journal of Food and Agro Industri. 3;349362.

Anggraini,D., Anita,. Dan Sestros Junita. 2013. Isolasi dan Uji Sifat Fisikokimia Pati Pisang Kepok (usa balbisiana L). Sekoah Tinggi Ilmu Farmasi. Riau.

Ansel,H.C. 1989. Pengantar Bentuk Sediaan Farmasi. ED 4. Alih Bahasa Oleh Farida Ibrahim. Universitas Indonesia. Jakarta.

Bender,D.A and Arnold,E.B. 1999. Bender's Dictionary of Nutrition and Food Tecnhologi. Seventh Edition. CRC Press. New York.

Departemen Kesehatan Republik Indonesia. 1995. Farmakope Indonesia. Ed 4.Direktorat Jendral Pengawasan Obat dan Makanan. Jakarta.

Departemen Kesehatan Republik Indonesia. 1979. Farmakope Indonesia. Ed 3. Direktorat Jendral Pengawasan Obat dan Makanan. Jakarta.

Dewati,R. 2008. Limbah Kulit Pisang Kepok Sebagai Bahan Baku Pembuatan Etanol. UPN Press. Jatim.

Gunawan,S.G. 2010. Farmakoogi dan Terapi. Ed 5. Universitas Indonesia. Jakarta.
Izidora,D.R.,Bogdan,D.J.,Chares,W. I.H. 2007. Granules Morphology and Rheological Behavior of Green Bnana (Musa Convendhisi) and Corn (Zea Mays) Strach Gels. Agrotec.31:5

Kanisius.1993. Jagung. Penerbit Kanisius. Yogyakarta.

Kusmartono,B. Dan Merita,I.W. 2012. Pembuatan susu dari kulit pisang dan kacang hijau. Didalam: Prosiding Seminar nasional aplikasi sains dan teknologi; Yogyakarta, 3 November 2012. Yogyakarta. ISNN.A241-A245.

Moechtar. 1990. Farmasi Fisika. Gadjah Mada University Press. Yogyakarta

Murry,J. 2007. Organic Cheistry. Thoson Brooks. Usa

Pakurar, A.S. \& Bigbee,, J.W., 2004. Digital Histology, an Interactive $C D$ Atlas With Review Text. Canada: John Wiley \& Sons, Inc.

Perdanakusuma, D.S., 2009. Surgical Management of Contracture In Head and Neck. Surabaya: Airlangga University School of Medicine.

Pradipta, I.G.N.D.O., 2010. Pengaruh Pemberian Propolis Secara Topikal Terhadap Migrasi Sel Polimorfonukleas Pada Luka Sayat Tikus. Jember: Fakultas Kedokteran Universitas Jember. Skripsi

Rahayu, F,. Wiwit Ade FW, Wiwik R., 2013. Pengaruh Pemberian Topikal Gel Lidah Buaya (Aloe 
chinensis Baker) Terhadap Repitelisasi Epidermis Pada Luka Sayat Kulit Tikus (Mus musculus). Riau: Fakultas Kedokteran Universitas Riau.

Rahayuningsih, T., 2012 Penatalaksaan Luka Bakar (Combustio). Prefesi 8: 1-13.

Rezende, G.P., Pimenta, F.C., Ribeiro. L., 2006. Antimicrobial Activity of Two Brazilian Coommersial Propolis Extracts. Bras J Oral Sci 5(16):967-970.

Rismana, E., Rosidah, I., Prasetyawan, Y., Bunga, O., \& Erna, Y. 2013. Efektivitas khasiat Pengobatan Luka Bakar Sediaan Gel Mengandung Fraksi Ekstrak Pegagang Berdasarkan Analisis Hidroksiprolin dan Histopatologi Pada Kulit Kelinci. Buletin Penelitian Kesehatan 41 (1): 4560.

Santoso, T., 2010. Perbedaan Kecepatan Kesembuhan Luka Bakar Antara Olesan Propolis 5\% dan Teh Hijau Konsentrasi 6,4gr\% Pada Tikus Putih (Rattus novergicur). Yogyakarta: PSIK 10 UMY. Skripsi.

Stein, C. \& Kucler, S., 2013. Targetting Inflammation and Wound Healing By Opioids. Elsevier 34(6): 300-312. Available from: http://www.sciencedirect.com/sci ence/article/pii/S0165614713000 473 [Accessed 28 April 2015]

Palupi, H.T. 2012. Pengaruh Jenis Pisang dan Bahan Perendam Terhadap Karakteristik Tepung Pisang (Mussa Spp). Jurnal Teknologi Pangan, 4:102-120
Poedjadi,A. 1994. Dasar-dasar Biokimia. UI Press. Jakarta

Prasetyo,J. 2015` . Optimasi Tablet Ibuprofen Menggunakan Amilum Kulit Pisang Sebagai Pengikat, Crospovidane Sebagai Penghancur dan Magnesium Stearat Sebagai Pelicin. (Skripsi). Surabaya.. Universitas Katolik Widya Mandala, Program Study S1

Purwono., R, Hartono. 2011. Bertanam Jagung Unggul. Penerbit Swadaya. Jakarta.

Rofikah. 2013. Pemanfaatan Pektin Kulit Pisang Kepok (Musa Paradisiacia Linn) Untuk Pembuatan Edible Film. (Skripsi). Semarang. Universitas Semarang.

Sastrohamidjojo,H. 2005. Kimia Organik. Gadjah Mada University Press. Yogyakarta.

Satria,B.H.dan yusuf,A. 2009. Pengolahan Kulit Pisang Menjadi Pektin Dengan metode Ekstraksi. Universitas Diponegoro. Semarang

Stevens,M.P. 2007. Kimia Polimer. Pradnya Paramita. Jakarta. 